\title{
Kinetic Studies of the Solvolyses of 4-Nitrophenyl Phenyl Thiophosphorochloridate
}

\author{
Han Joong Koh' and Suk Jin Kang \\ Deparment of Science Education, Jeonin National Lniversitu of Education. Jeonju 560-757, Korea \\ ${ }^{*}$ E-mail: hankohajnue kr \\ Received Mav 11. 2009. Accepted September +, 2009
}

\begin{abstract}
Rates of solvolyses of 4-nitrophenyl phenyl thiophosphorochloridate $\left(4-\mathrm{NO}_{2} \mathrm{PhOP}(\mathrm{S})(\mathrm{Cl}) \mathrm{OPh}, \mathbf{1}\right)$ in ethanol, methanol, and aqueous binary mixtures incorporating ethanol, methanol, acetone, and 2,2,2-tritluroethanol (TFE) are reported. Thermodynamic parameters were determined at several temperatures in three representative solvents. The extended Grunwald-Winstein equation was applied to 29 solvents and the correlation coefficient $(R)$ showed 0.959 . The sensitivities $(l=1.37$ and $m=0.62$ ) are sinular to those obtained for diphenyl thiophosphorochloridate

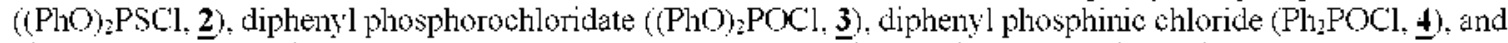
diphenyl thiophosphinic chloride ( $\left.\mathrm{Ph}_{2} \mathrm{PSCl}, \mathbf{5}\right)$. The solvolytic reaction mechanism of 4-nitrophenyl phenyl thiophosphorochloridate (1) is suggested to be proceeded a $S_{<} 2$ process as previously reported result. The activation enthalpies are shown as slightly low as $\Delta \mathrm{H}^{\dot{*}}=9.62$ to $11.9 \mathrm{kcal} \cdot \mathrm{mol}^{-1}$ and the activation entropies are shown as slightly high negative value as $\Delta \mathrm{S}^{+}=-34.1$ to $-44.9 \mathrm{cal}^{\prime} \mathrm{mol}^{-1} \cdot \mathrm{K}^{-1}$ compared to the expected $\mathrm{S}_{\mathrm{v}} 2$ reaction mechanism. Kinetic solvent isotope effects are accord with a typical $\mathrm{S}_{\mathrm{N}} 2$ mechanism as shown in the range of $2.41 \mathrm{in} \mathrm{MeOH}$ $\mathrm{MeOD}$ and 2.57 in $\mathrm{H}_{2} \mathrm{O} / \mathrm{D}_{2} \mathrm{O}$ solvent mistures.
\end{abstract}

Key Words: 4-Nitrophenyl phenyl thiophosphorochloridate. Extended Grunwald-Winstein equation, $\mathrm{S}_{\mathrm{N}} 2$ mechanism. Kinetic solvent isotope effects

\section{Introduction}

There have been several studies of the kinetics of nucleophilic substitution reaction of phosphoryl transfer reactions. A considerable amount of work has been carried out to clarify the problem whether phosphoryl transfer reactions proceed concertedly with a single transition state (TS) or via a stepwise mechanism with a pentacoordinated phosphorane intermediate.

Some researchers ${ }^{\mathrm{za}, \mathrm{b}}$ measured the rates of the py ridinolyses of phosphoryl py ridinium compounds and discussed the reaction mechanism using the slopes, $\beta_{\mathrm{m}) .4}$ and $\beta_{\mathrm{lg}}$ of the Bronsted plots. as a probe of the existence of intermediates in phosphoryl transfer reactions. They suggested mostly to be proceeded by a concerted substitution mechanism for the phosphoryl transfer reaction and the reaction is "exploded" a general TS shown as weak bonds between the distances of attacking group and leaving group.

The extended Grunwald-Winstein equation ${ }^{3-5}$ is used to correlate the specific rates of solvolysis reactions in terms of solvent ionizing power ${ }^{3}$ and solvent nucleophilicity. ${ }^{4 a}$ In equation ( 1 ), $\mathrm{k}$ and $\mathrm{k}_{0}$ represent the specific rate of solvolysis in a given solvent and one in the standard solvent $(80 \%$ ethanol), respectively: / represents the sensitivity to changes in solvent mucleophilicity $\left(\mathrm{N}_{\mathrm{T}}\right): m$ represents the sensitivity to changes in solvent ionizing power ( $\mathrm{Y}_{\mathrm{X}}$, for a leaving group $\mathrm{X}$ ): c represents a constant (residual) term.

$$
\log \left(\mathrm{k} / \mathrm{k}_{\mathrm{o}}\right)=/ \mathrm{N}_{\mathrm{T}}+m \mathrm{YX}_{\mathrm{X}}+\mathrm{c}
$$

Although the equation was initially developed for the nucleophilic attack at $\mathrm{sp}^{3}$-carbon, the scales. $\mathrm{N}_{\mathrm{T}}$ and $\mathrm{Y}_{\mathrm{x}}$ are also applied successfully to the mucleophilic attack sp ${ }^{2}$-carbon. ${ }^{5}$ phophonus. ${ }^{67}$ and sulfur. ${ }^{8}$ In the reported studies, a direct $\mathrm{S}_{\mathrm{N}} 2$ reaction mechanism is shown for the solvolytic reactions of dialkỵl, diaryl and phosphorochloridates possessing phosphorus reaction center as shown a good correlation fitted into the equation.

The direct $S_{\times} 2$ mechanism for the solvolytic recations have been exanined for the substrates. (PhO) $\mathrm{POCl}, \underline{\mathbf{3}}{ }^{(1)}$ diaryl $^{9}$ and dimethyl phosphorochloridates. (RO) $2 \mathrm{POCl}$, the sulfurfor-oxygen substituted dinetlyl phosphorocluloridothionate,

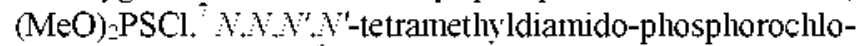
ridate. $\left(\mathrm{Me}_{2} \mathrm{~N}\right)_{2} \mathrm{POCl}^{6}$ and diphenylphosphinyl chloride, $\mathrm{Ph}$ POCl. ${ }^{\text {lla }}$ previously by Kevill and co-workers. The extended Gnuwald-Winstein equation plots for solvolyses of those substrates containing the $\mathrm{P}$-atom as the reaction center led to acceptable correlations with very similar $/$ and $m$ values. The mechanism of reactions of thiophosphinyl compounds such as 4-nitrophenyl phenyl thiophosphorochloridate (4- $\mathrm{NO}_{2} \mathrm{PhOP}$ (S)(Cl)OPl. 1) have been less studied. in spite of their intportance as highly unstable substrates. ${ }^{\text {? }}$

In this work. we investigated the solvolyses of 4-nitrophenyl phenylthiophosphorochloridate (1) in pure solvents and nuxed binary solvents to obtain exact kinetic information in various solvent systems as shown in equation (2). Particularly. we also investigated for the mechanistic difference owing to the change of the reaction substrates $(\underline{\mathbf{1}} \sim \underline{\mathbf{5}})$ of phospohoryl $(\mathrm{P}=\mathrm{O})$ or thiophosphoryl $(\mathrm{P}=\mathrm{S})$ and a phenyl or phenoxy group possessing $\mathrm{P}$ atom. In addition to the application of the extended Grunvald-Winstein equation to the specific rates, the influence of temperature on the specific rate in the three solvents has been discussed by calculated activation enthalpies and entropies. For understanding a further exact mechanistic informa- 
tion, the kinetic solvent isotope effect (KSIE). the kinetic runs were performed in deuterated methanol $(\mathrm{MeOD})$ and deuterated water $\left(\mathrm{D}_{2} \mathrm{O}\right)$.

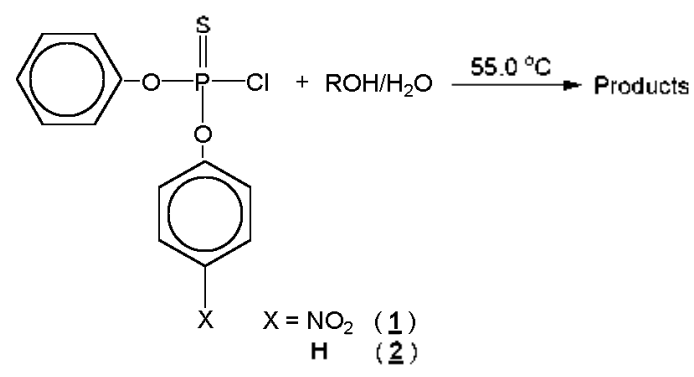

As further research of this series of work, we carried out kinetic studies of the solvolyses of 4-nitrophenyl phenyl thiophosphorochloridate (4-NO_PhOP $(\mathrm{S})(\mathrm{Cl}) \mathrm{OPh}, 1$ ), and the specific rates (first-order rate constants) are compared to those previously reported for the diphenyl thiophosphorochloridate $((\mathrm{PhO}) \leq \mathrm{PSCl}) .2)^{\text {l]c }}$ diphenyl phosphorochloridate ((PhO) $\mathrm{POCl}) .3)^{10}$ diphenyl phospluinic chloride $\left.\left(\mathrm{Ph}_{2} \mathrm{POCl}\right), 4\right){ }^{\text {l] }}$ and diphenyl thiophospinic clloride $(\mathrm{Ph}-\mathrm{P}(\mathrm{S}) \mathrm{Cl}), \underline{\mathbf{5}}){ }^{1 \mathrm{jb}} \mathrm{Our}$ purpose of this study is to draw a conclusion of an exact mechanism using the sensitivities. / and $m$ obtained from the extended Grunwald-Winstein equation (1) compared to the previously reported solvolytic reactions for $\mathbf{2} \sim \mathbf{5}$. The presence of an electron-withdrawing ligand ( $\left.4-\mathrm{NO}_{-} \mathrm{PhO}\right)$ in 1 is expected to lead the changes in the TS structure. which should be reflected in the magnitude of the $l$ and $m$ values. These solvolytic reactions could be influenced by the electronic interaction strongly between the reaction center $(\mathrm{P})$ and the electron withdrawing substituent, 4-NO2.

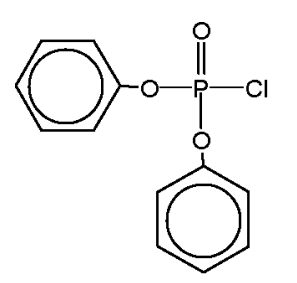

$\underline{3}$

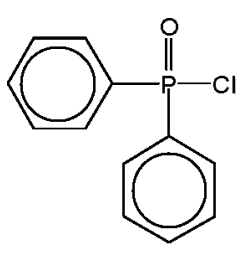

$\underline{4}$

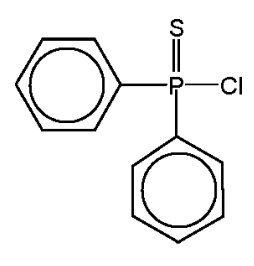

$\mathbf{5}$

\section{Results and Discussion}

The specific rates of solvolysis of 1 were determined at $55.0^{\circ} \mathrm{C}$ in 29 solvents. Used solvents are consisted of ethanol. methanol, and binary mixtures of water with ethanol, methanol, acetone, and 2,2,2-trifluroethanol (TFE). The rate constants are reported in Table 1 together with $\mathrm{Y}_{i \cdot]^{3}}$ and $\mathrm{N}_{\mathrm{T}}^{4}$ values. In order to compare with the previously reported kinetic results. the specific rates. at $55.0^{\circ} \mathrm{C}$. for the corresponding solvoly'ses of diphenyl thiophosphorochloridate (2) are also reported in Table 1.

The specific rates for 1 are summarized in Table 2 after the rate are measured at the three concentrations changing 0.550 . $1.021,2.112 \mathrm{~mol} \cdot \mathrm{L}^{-1}$ at $55.0^{\circ} \mathrm{C}$ for pure ethanol and $50 \%$ ethanol. The specific rates of solvolysis of 1 were not found to depend on the initial concentrations of the substrate. as shown
Table 1. Specific rates of solvolysis of 4-nitrophenyl phenvl thiophosphorochloridate $\left(4-\mathrm{NO}_{2} \mathrm{PhOP}(\mathrm{S})(\mathrm{Cl}) \mathrm{OPh}, 1\right)^{a}$ in various pure and mixed solvents at $55.0^{\circ} \mathrm{C}$, the $\mathrm{N}_{\mathrm{T}}$ and $\mathrm{Y}_{\mathrm{Cl}}$ values for the solvents, and the corresponding specific rate values $\left(\mathrm{k}^{\prime}\right)^{b}$ for diphenyl thiophosphorochloridate ((PhO) $\left.)_{2} \mathrm{PSCl}, 2\right)$.

\begin{tabular}{|c|c|c|c|c|}
\hline Solvent ${ }^{b}$ & $10^{3} k^{-6}\left(s^{-1}\right) 1$ & $10^{3} \mathrm{k}^{-c}\left(\mathrm{~s}^{-1}\right), 2^{d}$ & $\mathrm{~N}_{\tau}{ }^{e}$ & $\mathrm{Y}_{\mathrm{Cl}}{ }^{\prime}$ \\
\hline $100 \% \mathrm{EtOH}$ & $0.955 \pm 0.002$ & $0.0585 \pm 0,0007$ & 0.37 & -2.52 \\
\hline $90 \% \mathrm{EtOH}$ & $3.31 \pm 0.02$ & $0.526 \pm 0.003$ & 0.16 & -0.94 \\
\hline $80 \% \mathrm{EtOH}$ & $8.91 \pm 0.02$ & $0.789 \pm 0.007$ & 00 & 00 \\
\hline $70 \% \mathrm{EtOH}$ & $9.54 \pm 0.03$ & $1.10 \pm 0.03$ & -0.20 & 0.78 \\
\hline $60 \% \mathrm{EtOH}$ & $12.0 \pm 0.2$ & $1.64 \pm 0.04$ & -0.38 & 1.38 \\
\hline $50 \% \mathrm{EtOH}$ & $20.4 \pm 0.2$ & $2.41 \pm 0.07$ & -0.58 & 2.02 \\
\hline $40 \% \mathrm{EtOH}$ & $49.0 \pm 0.5$ & $4.58 \pm 0.04$ & -0.74 & 2.75 \\
\hline $20 \% \mathrm{EtOH}$ & $85.1 \pm 0.7$ & $10.2 \pm 0.3$ & -1.16 & 4.09 \\
\hline $100 \% \mathrm{MeOH}^{\mathrm{g}}$ & $1.91 \pm 0.02$ & $0.205 \pm 0.004$ & 0.17 & -1.20 \\
\hline $90 \% \mathrm{MeOH}$ & $4.90 \pm 0.04$ & $1.12 \pm 0.03$ & -0.01 & -0.20 \\
\hline $80 \% \mathrm{MeOH}$ & $10.5 \pm 0.2$ & $2.18 \pm 0.05$ & -0.06 & 0.67 \\
\hline $70 \% \% \mathrm{MeOH}$ & $27.5 \pm 0.3$ & $2.75 \pm 0.06$ & -0.40 & 1.46 \\
\hline $60 \% \mathrm{MeOH}$ & $52.5 \pm 0.4$ & $4.26 \pm 0.05$ & -0.54 & 2.07 \\
\hline $50 \% \mathrm{MeOH}$ & $83.2 \pm 0.7$ & $7.25 \pm 0.06$ & -0.75 & 2.70 \\
\hline $40 \% \mathrm{MeOH}$ & $151 \pm 3$ & $11.6 \pm 0.3$ & -0.87 & 3.25 \\
\hline $20 \% \mathrm{MeOH}$ & $324 \pm 7$ & $19.7 \pm 0.5$ & -1.23 & 4.10 \\
\hline $95 \%$ Acetone & $0.107 \pm 0.0012$ & $0.00178 \pm 0.00005$ & -0.49 & -3.19 \\
\hline $90 \%$ Acetone & $0.240 \pm 0.003$ & $0.0204 \pm 0.0004$ & -0.35 & -2.39 \\
\hline $80 \%$ Acetone & $0.956 \pm 0.006$ & $0.141 \pm 0.003$ & -0.37 & -0.83 \\
\hline $70 \%$ Acetone & $2.95 \pm 0.04$ & $0.417 \pm 0.006$ & -0.42 & 0.17 \\
\hline $60 \%$ Acetone & $13.8 \pm 0.3$ & $0.776 \pm 0.008$ & -0.52 & 1.00 \\
\hline $5(\% \%$ Acetone & $36.3 \pm 0.5$ & $2.02 \pm 0.05$ & -0.70 & 1.73 \\
\hline $40 \%$ Acetone & $52.5 \pm 0.8$ & $3.7+ \pm 0.07$ & -0.83 & 2.46 \\
\hline $30 \%$ Acetone & $95.4 \pm 1.2$ & $6.35 \pm 0.07$ & -0.96 & 3.21 \\
\hline $90 \% \mathrm{TFE}^{h}$ & $0.0891 \pm 0.0003$ & & -1.11 & 3.77 \\
\hline $80 \% \mathrm{TFE}$ & $0.363 \pm 0.002$ & $0.102 \pm 0.003$ & -1.23 & 4.28 \\
\hline $70 \% \mathrm{TFE}$ & $1.05 \pm 0.02$ & $0.154 \pm 0.004$ & -1.98 & 2.96 \\
\hline $50 \% \mathrm{TFE}$ & $5.25 \pm 0.03$ & $0.525 \pm 0.003$ & -1.73 & 3.16 \\
\hline $\mathrm{l}\left(00 \% \mathrm{H}_{2} \mathrm{O}\right.$ & $108 \pm 4$ & $10.2 \pm 0.3$ & -1.38 & 4.57 \\
\hline
\end{tabular}

"Unless otherwise indicated, a $10^{3} \mathrm{M}$ solution of the substrate in the indicated solvent containing $0.1^{1} \% \mathrm{CH}_{3} \mathrm{CN}$. "On a folume-Folume content at $25.0^{\circ} \mathrm{C}$, other component is water. 'With associated standard deviations. "Values from ref. $11 \mathrm{c}$. "Values from ref. $4 \mathrm{a},{ }^{\prime}$ Values from ref. 3. "Values of $k\left(=7.93( \pm 0.04) \quad 10^{-1} \mathrm{~s}^{-1}\right)$ in methanol- $d(\mathrm{MeOD})$, corresponding to kieon $\mathrm{k}_{\text {Meco }}$ value of $2.41 \pm 0.03$ [with associated standard error (Crumpler. T. B.; Yoh, J. H. Chentical Conpmutations and Enor; Wiley: New York. 1940: p 178)]. "Solvent prepared on a weight-eight basis at $25.0^{\circ} \mathrm{C}$. other component is water.

in Table 2.

For three kinds of solvents, specific rates of solvolyses of 1 were measured at three additional temperatures (Table 3 ). The enthalpies and entropies of activation calculated using these values are also presented in Table 3 .

In the present study, we are concerned with the specific rates of the solvolyses represented in equation (2). In most solvents, the reactions were proceeded fast. therefore we employed the conductivity measurements were followed to be able to record the responses to a function of time. ${ }^{12}$ In order to promote a rapid dissolution in the solvent. the substrate was added as a small volume of a concentrated stock solution in acetonitrile such 
Table 2. Specific rates of solvolyses of 4-nitrophenyl phenvl thiophosphorochloridate (1) in ethanol and ethanol-water with variation of the concentration of the substrate at $55.0^{\circ} \mathrm{C}$.

\begin{tabular}{|c|c|c|}
\hline Solvent & $\underline{1}, \mathrm{M}^{x}$ & $10^{3} \mathrm{k}^{3}, \mathrm{~s}^{.1}$ \\
\hline $100 \% \mathrm{EtOH}$ & $\begin{array}{l}0.530 \\
1.021 \\
2.112\end{array}$ & $\begin{array}{l}0.954 \pm 0.003 \\
0.953 \pm 0.002 \\
0.957 \pm 0.002\end{array}$ \\
\hline $80 \% \mathrm{EtOH}$ & $\begin{array}{l}0.530 \\
1.021 \\
2.112\end{array}$ & $\begin{array}{l}8.93 \pm 0.03 \\
8.89 \pm 0.03 \\
8.92 \pm 0.02\end{array}$ \\
\hline $50 \% \mathrm{EtOH}$ & $\begin{array}{l}0.530 \\
1.021 \\
2.112\end{array}$ & $\begin{array}{l}20.5 \pm 0.2 \\
20.2 \pm 0.3 \\
20.4 \pm 0.2\end{array}$ \\
\hline
\end{tabular}

${ }^{a}$ Concentration of stock solution in $\mathrm{CH}_{3} \mathrm{CN}$. ${ }^{\mathrm{k}}$ The $\mathrm{k}$ values are the averages of the result from at least three times kinetic runs and with associated standard deviation

Table 3. Specific rates and activation parameters for the solvolyses of 4 -nitrophenyl phenyl thiophosphorochloridate $(\underline{1})^{\sigma}$ in pure and aqueous solvents at various temperatures.

\begin{tabular}{|c|c|c|c|c|}
\hline Solvent & $\begin{array}{c}\text { Temp. } \\
\text { ("C) }\end{array}$ & $10^{2} \mathrm{k}^{b}\left(\mathrm{~s}^{-1}\right)$ & 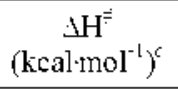 & $\begin{array}{c}- \pm \mathrm{S}^{-} \\
\left.\text {(cal } \cdot \mathrm{mol}^{-1} \cdot \mathrm{K}^{-1}\right)^{\mathrm{c}}\end{array}$ \\
\hline $100 \% \mathrm{EtOH}$ & $\begin{array}{l}25 \\
35 \\
45 \\
55\end{array}$ & $\begin{array}{l}0.194 \pm 0.002 \\
0.330 \pm 0.003 \\
0.562 \pm 0.004 \\
0.955 \pm 0.007\end{array}$ & $9.62 \pm 0.17$ & $44.9 \pm 0.6$ \\
\hline $80 \% \mathrm{EtOH}^{d}$ & $\begin{array}{l}25 \\
35 \\
45 \\
55\end{array}$ & $\begin{array}{l}1.42 \pm 0.03 \\
2.65 \pm 0.4 \\
4.82 \pm 0.4 \\
8.91 \pm 0.7\end{array}$ & $11.2 \pm 0.1$ & $34.1 \pm 0.5$ \\
\hline $100 \% \mathrm{MeOH}$ & $\begin{array}{l}25 \\
35 \\
45 \\
55\end{array}$ & $\begin{array}{l}2.92 \pm 0.02 \\
5.38 \pm 0.03 \\
1.02 \pm 0.03 \\
1.91 \pm 0.04\end{array}$ & $11.9 \pm 0.3$ & $37.6 \pm 0.7$ \\
\hline
\end{tabular}

${ }^{a} \mathrm{~A} 10^{-3} \mathrm{M}$ solution of the substrate in the indicated solvent, also containing $0.1^{0}, \mathrm{CH}_{3} \mathrm{CN}$. ${ }^{b} \mathrm{Ar}$ erages of three or more runs. with standard deviation. "The activation parameters are accompanied by the standard error. "On a colume-folume content at $25.0^{\circ} \mathrm{C}$. other component is water.

that the reaction solution contained about $0.1 \%$ acetonitrile.

The specific rates were observed to increase with increasing water content for binary aqueous mixtures. The specific rates of ethanoly sis of 1 were higher $\left(\mathrm{k}=9.55 \times 10^{-4} \mathrm{~s}^{-1}\right.$ at $\left.55.0^{\circ} \mathrm{C}\right)$ than that of ethanolysis of $2^{5.10}\left(\mathrm{k}=5.85 \times 10^{-5} \mathrm{~s}^{-1}\right.$ at $\left.55.0^{\circ} \mathrm{C}\right)$. This means that the solvents are contributed to make a tight bond in TS between the reaction center of phosphorus and the leaving group $(\mathrm{Cl})$ and to develop the bond cleavage of the leaving group $(\mathrm{Cl})$ a little high in the reaction of 1 equation (2).

Comparing with the difference of electron withdrawing ability between nitro group and hydrogen group which are substituted at para-position of phenyl ring. the positive charge of the reaction center. $\mathrm{P}$ in $\mathbf{1}$ is much higher than that in $\mathbf{2}$.

The rate for the solvolysis of $\mathbf{1}$ is much faster than that of 2 (Table 1). This is consistent with the substituent effect based on the electron withdrawing ability of the substrates. The rate of ethanolysis of $2\left(\mathrm{k}=5.85 \times 10^{-5} \mathrm{~s}^{-1}\right.$ at $\left.55.0^{\circ} \mathrm{C}\right)$ is lower than that of ethanolysis of $\underline{3}\left(\mathrm{k}=1.41 \times 10^{-4} \mathrm{~s}^{-1}\right.$ at $\left.0.0^{\circ} \mathrm{C}\right)$. It is indicates that the $\mathrm{P}=\mathrm{S}$ group is much favored to be lowered the leaving ability of $\mathrm{Cl}$ than of the $\mathrm{P}=\mathrm{O}$ group.

The specific rates change with substituents $\mathrm{X}(=\mathrm{H}$ and $4-\mathrm{NO}_{2}$ ) in according to those expected from solvolyses reactions with negative charge development at the reaction center (P) in the TS. The specific rates of $1\left(X=4-\mathrm{NO}_{2}\right)$ are faster than of $2(\mathrm{X}=\mathrm{H})$ at $55.0^{\circ} \mathrm{C}$. This is due to a greater positive charge on the $P$ atom in $\underline{1}$ (TS 1 ) than in $\underline{2}$ by the electron-withdrawing effect of the 4-NO $\mathrm{N}_{2}$ substituent in $\underline{1}$. which indicates of the inportance of bond making in the rate-determining step. $^{13}$

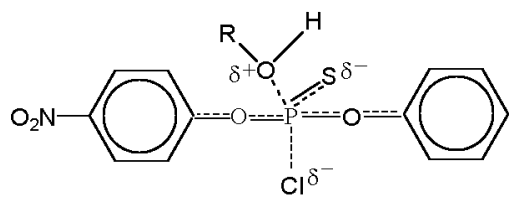

TS 1

The phenoxy group $\left(\sigma_{\mathrm{I}}=0.40\right)$ has a stronger electronwithdraw ing ability than the phenyl group $\left(\sigma_{\mathrm{I}}=0.12\right) .{ }^{14} \mathrm{Com}-$ paring with the difference of inductive effects between the phenoxy and the phenyl group. the positive charge of the reaction center $\mathrm{P}$ in $\underline{\mathbf{4}}$ (and $\mathbf{5}$ ) would be smaller than that in $\underline{1}$ (and $\underline{2}$ and $\underline{3}$ ). The specific rate constants of ethanolysis of $\overline{\mathbf{2}}$ are shown higher than that of $\mathbf{5}$ compared to the positive charge of the reaction center of $\overline{\mathrm{P}}$ aton. On the contrary. the observed rate of $\underline{5}\left(\mathrm{k}=1.20( \pm 0.02) \times 10^{-4} \mathrm{~s}^{-1}\right.$ in $100 \% \mathrm{EtOH}$ at $\left.25.0^{\circ} \mathrm{C}\right)$ is faster than that of $2\left(\mathrm{k}=8.72( \pm 0.02) \times 10^{-6} \mathrm{~s}^{-1}\right.$ in $100 \% \mathrm{EtOH}$ at $25.0^{\circ} \mathrm{C}$ ). This result inty that the reaction rate does not only depend on the positive charge of the reaction center $P$.

In the case of $\mathbf{5}$. two phenyl groups are attached to the reaction center $\mathrm{P}$ aton. whereas oxygen atons are intervened the interaction between the reaction center $P$ and the phenyl group in 2 . As a result. the steric hindrance would be shown nuch larger in $\underline{\mathbf{5}}$ than in $\underline{\mathbf{2}}$ when the solvent nucleopluiles attack the reaction center from the opposite of the leaving group, i.e., backside nucleophilic attack.

Some phosphate systems are more reactive than their thiophosphate counterparts by two or more orders of magnitude. ${ }^{15}$ Phosplinate systems are generally less sensitive to S substitution in the $\mathrm{P}=\mathrm{O}$ bond than phosphate sy stems: $\mathrm{k}_{\mathrm{P}=\mathrm{O}} / \mathrm{k}_{\mathrm{P}}=\mathrm{s}<10$ for the alkaline hydrolysis in $60 \%$ DME- $\mathrm{H}_{2} \mathrm{O}$ and $\mathrm{H}_{2} \mathrm{O}$ in a series of alkyl phosphinates. and $\mathrm{k}_{\mathrm{P}=\mathrm{O}} / \mathrm{k}_{\mathrm{P}=\mathrm{S}}=2.4 \sim 5.2$ for the hydroly ses of $\left(\mathrm{CH}_{3}\right)_{2} \mathrm{P}(\mathrm{O}) \mathrm{OPl} X$ and $\left(\mathrm{CH}_{3}\right)_{2} \mathrm{P}(\mathrm{S}) \mathrm{OPhX}{ }^{-\mathrm{j}}$ Our results, the rate ratio of $\mathrm{kP}_{\mathrm{P}=\mathrm{O}}(2) / \mathrm{k}_{\mathrm{P}=\mathrm{S}}(\underline{3})\left(=20\right.$ at $\left.55.0^{\circ} \mathrm{C}\right)$ is also consistent with the reported works. ${ }^{15}$ The $\mathrm{P}=\mathrm{O}$ systems are generally more reactive than their $\mathrm{P}=\mathrm{S}$ counterparts for several reasons. including the so-called thio effect which is mainly the electronegativity difference between $\mathrm{O}$ and $\mathrm{S}$ which favors $\mathrm{O}$ over S. $^{17}$

The activation parameters. $\Delta \mathrm{H}^{\circ}$ and $\Delta \mathrm{S}^{\neq}$, for solvolysis of $\underline{1}$ based on the specific rates at four temperatures in Table 3 are consistent with our proposed mechanism. The small positive $\Delta \mathrm{H}^{\neq}$values $\left(=9.62-11.9 \mathrm{kcal} \cdot \mathrm{mol}^{-1}\right)$ and large negative $\Delta \mathrm{S}^{\neq}$ values $\left(=-34.1 \sim-44.9 \mathrm{cal} \cdot \mathrm{mol}^{-1} \cdot \mathrm{K}^{-1}\right)$ are shown to be the 
characteristics of a kind of the relatively late TS with a large degree of bond making and leaving group departure. ${ }^{18}$ The large negative values of $\Delta S^{f}$ are accord with the characteristics of a kind of relatively late TS with a large bond cleavage which is not require much energy in the case of a strong leaving group. $\mathrm{Cl}^{\text {.j.k }}$ The large negative $\Delta \mathrm{S}^{\neq}$values may result from both large degree of bond cleavage and a strong steric hindrance in the bond making of the solvent.

Halmann ${ }^{19}$ reported of the specific rate of ethanoly sis of the

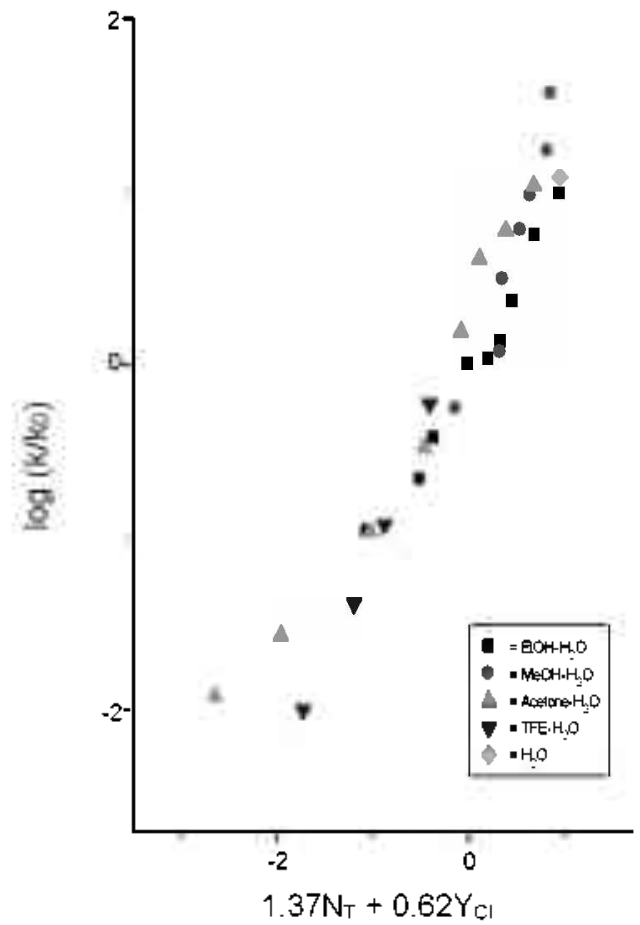

Figure 1. Plot of $\log \left(\mathrm{k} / \mathrm{k}_{\mathrm{i}}\right)$ for the solvoly ses of 4 -nitrophenyl phenyl thiophosphorochloridate (1) at $55.0^{\circ} \mathrm{C}$ against $\left(1.37 \mathrm{~N}_{\mathrm{T}}+6.62 \mathrm{Y}_{\mathrm{Cl}}\right)$. related diethylphosphinyl chloride. $\mathrm{Et}_{2} \mathrm{POCl}$. in the range of the concentration of $2.5 \times 10^{-3}$ to $17 \times 10^{.3} \mathrm{M}$. We found no perturbation of this tendency over a threefold variation at our lower concentrations $\left(0.5 \sim 2 \times 10^{-2} \mathrm{M}\right)$ of 1 undergoing solvolyses in $100 \%$ ethanol. $80 \%$ or $50 \%$ ethanol as shown Table 2 .

Calculated sensitivities obtained from the extended Grunwald-Winstein equation [eq. (1)] $]^{3-5}$ are shown as $1.37 \pm 0.11$ for $l$ and $0.62 \pm 0.04$ for $m$ in 29 solvents as shown in Table 1 and Figure I with a multiple correlation coefficient of 0.959 . Sensitivity values, $l$ and $m$ are well correlated as shown in Table + compared with the other values reported for similar substrates. ${ }^{20.3}$

Therefore the determination of these values will be a valuable source of information concerning the structure of the transition state for these solvoly ses. ${ }^{21}$ The $l$ and $m$ values for the solvolysis of 1 were compared with recently reported results as shown in Table 4 after analyzed in ternis of equation ( 1 ) for the specific rates of solvolyses of diphenyl thiophosphorochloridate. ${ }^{910}$ diphenyl phosphinyl chloride. ${ }^{1]}$ isopropyl sulfonylchloride. $V_{,} N$-dimethyl sulfamoylchloride, 2 -phenyl2-ketoethyl tosylate. ${ }^{22}$ dimethyl thiophosphorochloridate. ${ }^{7}$ and $N . N . N^{\prime} Y^{\prime}$-tetramethyl dimidophosphorochloridate. ${ }^{6}$ The / value of 1.37 and the $m$ value of 0.62 for the solvolysis of 1 were very similar to the previously reported values for the bimolecular solvoly'ses of other substrates (Table 4), ${ }^{6-8.27}$ which suggests an $\mathrm{S}_{\mathrm{N}} 2$ mechanism involving an attack by the solvent at phosphorus atom of 1 . The solvolysis of 1 , where bond making $(l=1.37)$ is more progressed than bond breaking $(m=$ 0.62 ). and the values are still in the range of $\mathrm{S}_{\mathrm{v}} 2$ mechanism, reflecting on the degree of the nucleophilic assistance based on the measure of solvent nucleophile. ${ }^{2 i c}$

For the solvoly sis of 1 . the ratio of $l m$ value was calculated as 2.2 which is similar to those of $\mathrm{N}$-dimethyl sulfamoyl chloride, ${ }^{23}$-phenyl-2-ketoethyl-tosylate, dimethyl thiophos-

Table 4. Extended Grunwald-Winstein correlations of the specific rates of solvolyses of solvolytic displacements of chloride from phosphorus.

\begin{tabular}{|c|c|c|c|c|c|}
\hline Substrate & $11^{a}$ & $l^{b}$ & $m^{2}$ & $\mathrm{R}^{\mathrm{c}}$ & $l m$ \\
\hline $4-\mathrm{NO}_{2} \mathrm{PhOP}(\mathrm{S})(\mathrm{Cl}) \mathrm{OPh}$ & 29 & $1.37 \pm 0.11$ & $0.62 \pm 0.04$ & 0.959 & 2.2 \\
\hline$\left(\mathrm{PhO}_{2}\right)_{2} \mathrm{PSCl}^{1] c}$ & 27 & $1.12 \pm 0.11$ & $0.61 \pm 0.02$ & 0.990 & 1.8 \\
\hline $\mathrm{Ph}_{2} \mathrm{PSCl}^{d}$ & 29 & $1.03 \pm 0.08$ & $0.66 \pm 0.05$ & 0.933 & 1.6 \\
\hline $\mathrm{Ph}_{2} \mathrm{PSCl}^{*}$ & 25 & $1.00 \pm 0.04$ & $0.64 \pm 0.03$ & 0.983 & 1.6 \\
\hline $\mathrm{Ph}_{2} \mathrm{POCl}^{f}$ & 31 & $1.44 \pm 0.13$ & $0.58 \pm 0.09$ & 0.920 & 2.5 \\
\hline $\mathrm{Ph}_{2} \mathrm{POCl}^{e}$ & 27 & $1.42 \pm 0.10$ & $0.54 \pm 0.07$ & 0.956 & 2.6 \\
\hline $\mathrm{Ph}_{2} \mathrm{PCl}^{\%}$ & 29 & $1.31 \pm 0.14$ & $0.51 \pm 0.09$ & 0.899 & 2.6 \\
\hline $\mathrm{Pl}_{2} \mathrm{PCl}^{e}$ & 25 & $1.25 \pm 0.09$ & $0.46 \pm 0.06$ & 0.954 & 2.7 \\
\hline$(\mathrm{MeO})_{2} \mathrm{POCl}^{h}$ & 22 & $1.36 \pm 0.23$ & $0.54 \pm 0.13$ & 0.844 & 2.5 \\
\hline$(\mathrm{MeO})_{2} \mathrm{POCl}^{e, t}$ & 18 & $1.24 \pm 0.14$ & $0.45 \pm 0.08$ & 0.941 & 2.8 \\
\hline$(\mathrm{MeO})_{2} \mathrm{PSCl}^{\prime+}$ & 31 & $1.21 \pm 0.10$ & $0.60 \pm 0.04$ & 0.943 & 2.0 \\
\hline$(\mathrm{MeO})_{2} \mathrm{PSCl}^{\mathrm{e} h_{2}}$ & 28 & $1.16 \pm 0.08$ & $0.55 \pm 0.03$ & 0.966 & 2.1 \\
\hline$\left(\mathrm{Me}_{-} \mathrm{N}_{2} \mathrm{POCl}^{\prime}\right.$ & 31 & $1.20 \pm 0.07$ & $0.69 \pm 0.04$ & 0.958 & 1.7 \\
\hline$\left(\mathrm{Me}_{2} \mathrm{~N}_{2}\right)_{2} \mathrm{POCl}^{\mathrm{e}, l}$ & 27 & $1.14 \pm 0.05$ & $0.63 \pm 0.03$ & 0.982 & 1.6 \\
\hline$\left(\mathrm{PhO}_{2}\right)_{2} \mathrm{POCl}^{j}$ & 29 & $1.31 \pm 0.10$ & $0.61 \pm 0.04$ & 0.960 & 2.1 \\
\hline
\end{tabular}

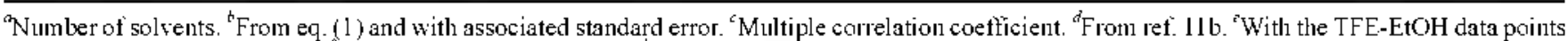
excluded from the correlation. 'From ref. 11 a. ${ }^{\text {s}}$ From ref. $26 .{ }^{\prime \prime}$ From ref. $7 .{ }^{\prime}$ From ref. $7 .{ }^{\prime}$ From ref. 10. 
phoroclloridate. ${ }^{7}$ and $X, N_{,}{ }^{\prime} . X$-tetramethyldiamido-phosphorochloridate ${ }^{6}$ to suggest the $\mathrm{S}_{\mathrm{V}} 2$ mechanism.

We found that the use of $\mathrm{N}_{T}$ values in conjunction with $\mathrm{Y}_{\mathrm{Cl}}$ values led to acceptable correlations. with similar $/$ and $m$ values compared with those obtained in the analyses of the specific rates of solvolyses for other entries in Table 4 . The only difference is smaller $/$ value for the solvolysis of 1 . possibly reflecting a decreased nucleophilic participation at the TS due to reduced electronegativity of the $\mathrm{P}=\mathrm{S}$ compared to the $\mathrm{P}=\mathrm{O}$.

In methanol and methanol-d (MeOD), a KSIE $\left(\mathrm{k}_{\mathrm{MeOH}} /\right.$ $\left.\mathrm{k}_{\mathrm{MeOD}}\right)$ of $2.4 \mathrm{I} \pm 0.03$ at $55.0^{\circ} \mathrm{C}$ is observed $\left(\mathrm{k}_{\mathrm{MeOD}}=7.93( \pm\right.$ $0.04) \times 10^{-4} \mathrm{~s}^{-1}$ ). This result is in the range $1.58 \pm 0.05$ to 2.31 \pm 0.07 which were observed ${ }^{24}$ for the corresponding methanoly ses of a series of benzenesulfonyl chlorides at $25.0^{\circ} \mathrm{C}$. in which the reactions were believed to be $\mathrm{S}_{\mathrm{N}} 2$ in character. The methanolyses of meta- and para-chlorobenzyl chloride and para-nitrobenzyl chloride, believed to be $\mathrm{S}_{\mathrm{N}} 2$ in character. also showed values in the range from $1.49 \pm 0.05$ to $1.89 \pm$ $0.077^{-5}$ Reported values have indicated that values in these ranges can be considered as good supporting evidence for the postulation of an $\mathrm{S} v 2$ mechanism for a methanolysis. In water $\left(\mathrm{H}_{2} \mathrm{O}\right)$ and deuterated water $\left(\mathrm{D}_{2} \mathrm{O}\right)$, a KSIE of $2.57 \pm 0.06 \mathrm{at}$ $55.0^{\circ} \mathrm{C}$ is also observed $\left(\mathrm{k}_{\mathrm{D} O \mathrm{O}}=4.20( \pm 0.02) \times 10^{-2} \mathrm{~s}^{-1}\right)$. On the basis of the observed KISE value, the possibility of a $\mathrm{S}_{\mathrm{N}} 1$ mechanism for the hydrolysis of 1 could be excluded. ${ }^{2+35}$

In summary the solvolyses of 4-nitrophenyl phenyl thiophosphorochloridate (1) in ethanol. methanol, and aqueous binary mixture incorporating ethanol. methanol. acetone. and TFE at $55.0^{\circ} \mathrm{C}$ are proceed with a concerted $\mathrm{S} \mathrm{N} 2$ process with a late TS. The result was drawn on the base: (1) similar sensitivities $(l=1.31$ and $m=0.62$ ) with those obtained for diphenyl thiophosphorochloridate (2), diphenyl phosphorochloridate (3). diphenyl phosphinic clloride (4) and diphenyl thiophosphinic clloride (5): (2) the large kinetic solvent isotope effects $\left(=2 .+1 \mathrm{in} \mathrm{MeOH} / \mathrm{MeOD}\right.$ and 2.57 in $\left.\mathrm{H}_{2} \mathrm{O} / \mathrm{D}_{2} \mathrm{O}\right)$ : and (3) small $\Delta \mathrm{H}^{=}$with large negative $\Delta \mathrm{S}^{\circ}$ values.

\section{Experimental}

Solvents were purified as previously described. ${ }^{25}$ The substrate did not react with the pure acetonitrile within the stock solution. 4-Nitrophenyl phenyl thiophosphorochloridate (1) was prepared by reacting phenyl phosphorodichloridothionate with 4-nitro-phenol. The phenyl phosphorodichloridothionate (Aldrich $98 \%$ ) was used as received. A solution of phenyl phosphorodichloridothionate $0.01 \mathrm{~mol} \mathrm{in} 15 \mathrm{~mL}$ of HPLC grade acetonitrile was added to a solution of required amount of 4-nitro-phenol for $0.01 \mathrm{~mol}$ and $0.01 \mathrm{~mol}$ of triethylamine in $15 \mathrm{~mL}$ of the same acetonitrile on an ice bath. The solution was stirred on an ice bath for 2 hours. Triethylamine hydrochloride salt was separated by filtration. Acetonitrile was evaporated under reduced pressure. The remaining product was treated with ether and water for work-up. and $5 \%$ $\mathrm{NaHCO}_{3}$ solution was treated to remove excess 4-nitrophenol. After work-up, anlydrous $\mathrm{MgSO}_{4}$ was added, kept + hours. and the solvent was removed under reduced pressure by using the rotary evaporator after removing $\mathrm{MgSO}_{4}$ by filtration.
Finally, the product was passed through colunm clurontatography (ethyl acetate + n-hexane) for purification. $\left(\mathrm{NO}_{2} \mathrm{C}_{3} \mathrm{H}_{4}\right.$ $\left.\mathrm{OP}(\mathrm{S})(\mathrm{Cl}) \mathrm{OC}_{6} \mathrm{H}_{5}\right)$ : Liquid. Calc. for $\mathrm{C}_{12} \mathrm{H}_{9} \mathrm{O}_{4} \mathrm{PSNCl}$ : C. 43.72 : $\mathrm{H}, 2.75$. Found: C. 43.69: H, 2.79\%. ${ }^{\mathrm{l}} \mathrm{H}-\mathrm{NMR}, \delta_{\mathrm{H}}\left(\mathrm{CDCl}_{3}\right) 6.6$ 8. $1\left(\mathrm{OC}_{6} \mathrm{H}_{5}-\mathrm{H}+\mathrm{OC}_{6} \mathrm{H}_{4} \mathrm{NO}_{2}-\mathrm{H}_{2} 9 \mathrm{H}_{2} \mathrm{~m}\right), m / 2329\left(\mathrm{M}^{+}\right)$.

The kinetic experiments were carried out by allowing a conductivity cell containing $12.5 \mathrm{~mL}$ of solvent to equilibrate. with stirring. in a constant-tenperature water bath. A $12 \mu \mathrm{L}$ portion of a $1.0 \mathrm{~mol} \mathrm{dm}^{-3}$ stock solution of 1 in acetonitrile was then added. The monitoring of increases in conductivity with time and the calculation of the specific rates (first-order coefficients) were conducted as previously reported. ${ }^{\text {ll }}$ The multiple regression analyses were performed using commericially available packages.

\section{References}

1. (a) Page, M.: Walliams, A. Orgonic and Bio-Orgonic lechanisms; Longman: Harlow, 1997; Chapter 7-8. (b) Williams, A. Concented Organic and Bio-Organic Mechanisms; CRC Press: Boca Raton, 2000: Chapter 6. (c) Hudson. R. F. Strictue and M lechanism in Organophosphons Chemistny. Academic Press: New York, 1965. (d) Admiral, S. J.; Schneider, B.; Mever, P.; Janin, T.; Veron, M; Deville-Bonne, D.; Herschlag, D. Biochemistry 1999, 38, 4701. (e) Mol C. D.; Izumi, T.; Mitra, S.: Tainer, J. A. Natwe 2000, 403,451 . (f) Hostield, D. J.: Guan, Y :; Hals, B. J.: Cunningham, R. P.: Tainer, T. A. Cell 1999, 98, 397 (g) Mol. C. D.; Hosfield, D. T: Tainer, J. A. Hitat Res. 2000, 460,211 . (h) Chapados, B. R.; Chai, Q.; Hosfield, D. J.; Qiu, T.; Shen, B.; Tainer, T. A. Mol Biol 2001, 307, 541

2. (a) Boume. N.: Williams, A. J. Am. Chem Soc. 1984, 106. 7591. (b) Skoog. M. T. Tencks, W. P. J. Am. Chem. Soc 1984, 106 , 7597. (c) Kirby, A. J.; Varroglis, A. G. J Am. Chem. Soc. 1967, 89, 415. (d) Friedman, T. M.; Freeman, S.; Knowles, T. R. J. Am. Chem. Soc. 1988, 110, 1268. (e) Bourne, N.; Chrystiuk, E; Davis, A. M.: Williams, A. J. Am. Chem. Soc 1988, 110, 1890. (f) Ba-Saif, S. A.: Waring, M. A.; Williams, A. J. Am. Chem. Soc. 1990, 112, 8115 . (g) Hengge, A. C.; Edens, W. A.; Elsing. H. $J$. Ant Chem. Soc 1994, 116,5045. (h) Hoff, R. H.: Hengge, A. C. J. Ong. Chem 1998, 63, 6680. (i) Guha, A. K.: Lee, H. W.; Lee, I. J. Chem. Sac, Perkin Trans. 2 1999, 765. (j) Hoque, Md. E. U.: Dey, N. K.: Guha, A. K: Kim, C. K.: Lee, B.-S.: Lee, H. W. Bull Korean Chem. Soc. 2007, 28, 1797. (k) Hoque, Md. E. U.; Lee, H. W. Bull. Konean Chem. Soc. 2007, $28,936$.

3. (a) Grunwald, E:; Winstein, S. J. Am. Chem. Soc 1948, 70,846. (b) Bentley, T. W.; Llewellyn, G. Prog. Phvs. Org. Chent. 1990. 17, 121. (c) Kevill, D. N.; D'Soluza, M. I. J. Chem. Res. Synop. 1993, 174. (d) Bentley, T. W.: Carter, G. E. J. Am. Chem. Soc. 1982, 104, 5741 , (e) Koo, I. S.; Bentley, T. W: Kang, D. H.: Lee, I. J. Chen. Soc, Perkin Trans. $21991,296$.

4. (a) Winstein, S.; Grunwald, E; Tones, H. W. J. Am. Chem. Soc. 1951, 73,2700 (b) Kevill, D. N.: Anderson, S. W. J. Oig. Chem. 1991, 56, 1845. (c) Kevill, D. N. In Adrances in Quantitative? Snncture-Properth Relationships: Charton, M., ed. IAI Press: Greenwich, CT, 1996; Vol. 1, pp 81 115.

5. Kevill, D. N.; D'Souza, M. T. J. Chent. Soc. Perkin Trons. 2 1997,1721

6. Kevill. D. N.: Miller. B. J. Ong. Chem. 2002, 67.7399

7. Kevill, D. N.; Carver, J. S. Org. Biomol Chem 2004, 2, 2040.

8. Kevill, D. N.; Park, B. C.; Park, K. H.; D'Souza, M. J : Yaakoubd, L.; Mlynarski, S. L.; Kyong, J. B. Org. Bionol. Chem. 2006, f, 1580.

9. Bentley, T. W.: Ebdon, D.; Llewellyn, G.; Abdulaber, M. H.; Miller. B.: Kevill. D. N. J. Chem. Soc. Dalton Trans. 1997. 3819. 
10. Kevill, D. N.; Kol, H. T. Manuscript in preparation.

11. (a) Kevill, D. N.; Koh, H. J. J. Phvs. Org Chem. 2007, 20,88. (b) Koll, H. I.: Kan1, S. J.: Kevill, D. N. Bull Korean Chem. Soc. 2008, 29, 1927. (c) Koh, H. T.: Kang, S. T.; Kevill, D. N. Bull. Korean Chem. Soc. $\mathbf{2 0 0 9}, 30,383$.

12. (a) Bentley, T. W.; Ebdon, D. N. J. Phys. Org. Chem. 2001, 14 , 759. (b) Koh, H. J.: Han, K. L.: Lee, H. W.: Lee, I. J. Org. Chem. $1998,63,9834$.

13. Lee, H. W.; Gulha, A. K. Lee, I. Int. J. Chem. Kinet. 2002, 3t, 632.

14. Charton, M. Prog. Phys. Org. Chem. 1987, 16, 287

15. (a) Neimysheva, $\AA$. A.; Savclik, V.; Emolaeva, M. V.; Knunyants, I. L. Bull. Acad Sci. LSSR Div. Chen. Sci. Eng Trans. 1968, 2104 . (b) Ketelaar, I. A. A.: Gresmann, H. R, Koopmans, K. Recl. Trav. (Thm. Pavs-Bas 1952, 71, 1253. (c) Chlebowski, I. F.: Coleman, J. E. J. Biol. Chem. 1974, 247,7192.

16. Cook, R. D.; Farah, S.; Ghawi, L.; Itani, A.; Rahil, J. Can. J. Chem. $1986,64,1630$.

17. (a) Bel" skii. V. E.: Bezzubova, N. N.: Akannsin, V. D.: Elisentkov, V. N.: Rizpolozhenskii, N. I.: Puduvik, A. N. Dokl thad. Nauk. SSSR 1971, 197, 85: Eng Trans. p. 171. (b) Onyido, I: Swierczek, K.; Purcell, T. Hengge, A. C. J. Ant. Chent. Soc. 2005, 127, 7703. (c) Donglas, K. T.: Willianns, A. J. Chem. Soc. Perhin Trans. 21976,515 . (d) Un, I. H.: Akhtar, K.: Shin, Y. H.: Han, J. Y. J. Org. Chem 2007, 72, 3823. (e) Cook, R. D.: Daouk, W. A.; Haij, A. N.; Kabbani, A.; Kurku, A.; Samaha, M.; Shavban, F.; Tanielian, O. V. Can. J. Chem. 1986, 6t, 213
18. (a) Lee, I.: Sung. D. D.: Uhm, T. S.: Ryul, Z. H. J. Chem. Soc., Pewhin Trans. 2 1989, 1697. (b) Yew, K. H.: Koh, H. I.; Lee, H. W. Lee, I. J. Chem. Soc. Perlin Trans. 2 1995. 2263.

19. Halmann, M. Phosphons Sulfur 1988, 40, 251.

20. Lee, S. H.: Rhu, C. J.: Kvong, T. B.: Kim. D. K.; Kevill, D. N. Bull Korean Chem. Soc 2007, 28,657.

21. (a) Kevill. D. N.: D'Solza, M. J. J. Org. Chem. 1998, 63, 2120. (b) Kyong, J. B.; Park, B. C.; Kim, C. B.; Kevill, D. N. J. Org. Chem. 2000, 65,8051. (c) Kevill. D. N.: D'Souza, M. J. Collect. Czech. Chem. Commm 1999, 64, 1790. (d) Bentley, T. W.; Jones, R. O.: Koo, I. S. J. Chem. Soc. Pewin Trans. $21994,753$. (e) Kevill, D. N.; D'Souza. M. J. J. Phys. Org. Chem. 2002,15, 881. (f) Kyong, J. B.; Won, H. S.; Lee, Y. H.; Kevill, D. N. Bull. Korean Chem. Soc. 2005, 26,661.

22. Kevill, D. N.: Kim. C. B. J. Oig. Chem. 2005, 70, 1490.

23. (a) Kyong. I. B.: Kim. Y. G.: Kim. D. K.: Kevill. D. N. Bull. Korean Chent. Soc: 2000, 21, 662. (b) Kevill, D. N.; Kyong, J. B. Weitl. F. L. J. Ong. Chent $1990,55,4304$. (c) Kvong, T. B.; Ryu, S. H.; Kevill, D. N. Int. J. M /ol. Sci. 2006, 7, 186. (d) Kevill, D. N.; D Souza, M. T. J. Org. Chem. 2004, 69, 7044 (e) Kyong: J. B.: Won, H. S.; Kevill, D. N. Int. J. Hot. Sci. $2005,6,87$.

24. Koo, I. S.; Lee, I; Oh, J. U.; Yang, K. Y ; Bentley, T. W. J. Phys. Org. Chem. 1993, 6, 223

25. Lee, I.: Koh, H. J.: Park, Y. S.: Lee, H. W. J. Chem. Soc. Perhin Trans. 2 1993, 1575

26. Koh, H. T, Kang, S. J.; Kevill, D. N. Phosphorts, Sulfur, and Silicon 2008, 183, 364. 